\title{
Neglect of people with disability by the African church
}

\begin{tabular}{|c|c|}
\hline $\begin{array}{l}\text { Author: } \\
\text { Maake J. Mas }\end{array}$ & ango $^{1}$ (1) \\
\hline $\begin{array}{l}\text { Affiliation: } \\
{ }^{1} \text { Department } \\
\text { Theology, Fac } \\
\text { Theology and } \\
\text { University of } \\
\text { Pretoria, Sou }\end{array}$ & $\begin{array}{l}\text { of Practical } \\
\text { ulty of } \\
\text { Religion, } \\
\text { Pretoria, } \\
\text { h Africa }\end{array}$ \\
\hline $\begin{array}{l}\text { Research Proj } \\
\text { Project Leade } \\
\text { Project Numb }\end{array}$ & $\begin{array}{l}\text { ect Registration: } \\
\text { r: M.J. Masango } \\
\text { er: } 02467526\end{array}$ \\
\hline $\begin{array}{l}\text { Project descri } \\
\text { This research } \\
\text { project, 'Pastc } \\
\text { Trauma Couns } \\
\text { by Prof. Dr Mc } \\
\text { Department o } \\
\text { Theology, Fac } \\
\text { Theology, Uni } \\
\text { Pretoria. }\end{array}$ & $\begin{array}{l}\text { ption: } \\
\text { is part of the } \\
\text { ral Care and } \\
\text { elling', directed } \\
\text { aake Masango, } \\
\text { f Practical } \\
\text { ulty of } \\
\text { versity of }\end{array}$ \\
\hline $\begin{array}{l}\text { Correspondin } \\
\text { Maake Masan } \\
\text { maake.masan }\end{array}$ & $\begin{array}{l}\text { g author: } \\
\text { go, } \\
\text { go@up.ac.za }\end{array}$ \\
\hline $\begin{array}{l}\text { Dates: } \\
\text { Received: } 26 \\
\text { Accepted: } 10 \\
\text { Published: } 05\end{array}$ & $\begin{array}{l}\text { une } 2019 \\
\text { Aug. } 2019 \\
\text { Dec. } 2019\end{array}$ \\
\hline $\begin{array}{l}\text { How to cite th } \\
\text { Masango, M.J } \\
\text { ‘Neglect of pe } \\
\text { disability by tl } \\
\text { church', HTS T } \\
\text { Studies/Theol } \\
\text { 75(4), a5631. } \\
\text { 10.4102/hts.V }\end{array}$ & $\begin{array}{l}\text { is article: } \\
\text { 2019, } \\
\text { ople with } \\
\text { e African } \\
\text { eologiese } \\
\text { gical Studies } \\
\text { https://doi.org/ } \\
75 i 4.5631\end{array}$ \\
\hline $\begin{array}{l}\text { Copyright: } \\
\text { (C) 2019. The A } \\
\text { Licensee: AOS } \\
\text { is licensed und } \\
\text { Creative Comr } \\
\text { Attribution Lic }\end{array}$ & $\begin{array}{l}\text { uthors. } \\
\text { IS. This work } \\
\text { der the } \\
\text { nons } \\
\text { ense. }\end{array}$ \\
\hline Read online: & \\
\hline 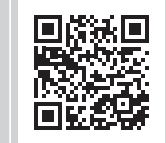 & $\begin{array}{l}\text { Scan this QR } \\
\text { code with your } \\
\text { smart phone or } \\
\text { mobile device } \\
\text { to read online. }\end{array}$ \\
\hline
\end{tabular}

The African community, as well as the church, has always cared for people with disability. The main problem they faced is that they care for them by imposing their own agenda on them. In other words, they take over their lives by over-caring. Because of guilt, they want to do everything for them, as if they are not capable of functioning within that community. This way of caring leads to them over-protecting these people. The process of caring over-shadows people with disability. They simply take over their lives, which results in the fact that these people become object of those who care for them. They are called names and are described by their function or through their disability. This is how they lose their name in life. The above discussion simply explain this object relational syndrome. For example, they are called digole (handicapped). In brief, they lose who they are, when the community uses their characteristic instead of their names, and behaviour becomes a way of dealing with them. The African church finally endorses the above by removing the image and likeness of God from them. For example, when they attend worship, they are viewed as people who are not normal, and in need of prayer, for healing so that they can be normal like us. This is another way of dealing with them as objects. Another obstacle in the African church is lack of ramps. The church is expecting the so-called normal people who function in a way that they want. This is a sign that people with disability are not welcomed. Finally, they are viewed as people possessed by demons and therefore in need of healing. The church, without finding out what they need, sets the agenda. The reader will now understand why the African church has neglected them.

Keywords: people; disability; church; pastoral care; African church; African communities; Accessibility; Inclusion of people with disabilities; Caring for people with disabilities; The church and people with disabilities.

\section{Introduction}

African villages or communities have always lived with people with disabilities for a long time. The only recollection of my experience with people with disability is what we used to call them in those days. My recollection connects me to a negative perspective, especially in that community in which I lived. As I write this article, I realise how they were discriminated against, isolated and rejected by certain members of the village. This happened to such an extent that some of their families hid them from participating or being visible in that community of Atteridgeville. For example, in that community, as children we were scared of them. One of them was called 'nana' and another one 'Chimbe'. The two of them moved around the township singing a song like 'nana o kae' [Nana where are you?]. As children, we used to tease and mock them. Some adults responded differently to us by scolding and chastising us, while others responded negatively towards them; as a result, they were stigmatised by the community. Other people would give them food and care for them. I do not recall how the church took care of both of them. I also remember the names they were called by: digole [crippled], disabled (not able to do things for themselves) and handicapped. (In short, they were not normal like us, so to speak.) In other words, they were called by their physical disability, and not by their names. One could say that the community striped them off their human dignity.

From the look of things, in that community, it appears that nobody knew their names. They were referred by what people saw in them. My memory of Nana placed him in our home where he used to visit most, especially during dinner time. This visit disturbed us (siblings) as children because we had to share some of the food with him. This visit became a problem in such a way that my brother and I sat at the gate during supper time in order to chase him away. We would tell him that mother was not there to feed him. When our parents discovered this, we were punished by giving him a portion of our meal for the whole month, especially meat. Nana was so happy

Note: HTS 75th Anniversary Maake Masango Dedication. 
and would continue singing as he was eating our share of meat. The above action or punishment was done in order to teach us to care for people with disability. Looking back at this story, I now realised that our parents wanted Nana to be included as part of our family, so we tolerated him, but did not like him. In brief, our parents were trying to develop a positive attitude in us so that we could respect people with disability. Longchar (2011:35) says that '[d]isability is the oppression of and a barrier against people with impairment'. This quotation reminds me of how as children we use to view them. I realised that we were obstructed by culture and the myth created in our country that they were not fully human. In other words, they were abnormal because they did not look like us. Hence, they were called by different names. No wonder they were referred to as handicapped, disabled (digole - not fully developed) and differently abled (we were normal and they were abnormal). In other words, they were not normal people because normality was associated with not having impairment. The African community lumps disabled persons together and analyses them in terms of their bodily impairment. Writing this article made me aware of different kinds of disabilities such as mild, moderate, severe or profound disability. One can also look at psychological impairment. There are also psychological hearing impairment, learning disability, autism, Downe's syndrome, intellectual disability and so forth. As we grew up, the above issues were not mentioned in our community, let alone in our vocabulary. In our minds, all we saw was bodily disability. This view limited us and gave us a negative attitude towards people with disability. It also had a great impact on the quality of life, development and rights which we created in such a way that we oppressed them, rejected and isolated them in the community because they were not like us. The myth which was created by the community made us see people with disability as punished by God. Other African communities see it as the divine will, or see them as people who are bewitched, among other suspicions. This kind of grooming made us invite doom on people with disabilities and their families. In other words, the view of disability was based on a curse from God, connecting it with the notion of Old Testament which views sin and disability as sinful acts committed either by parents or by any adult members of the family. This punishment from God finally punished their children from fourth to fifth generation. We will then use passages from scriptures in order to justify our argument. According to Deuteronomy 28:28, ' $[t]$ he Lord will smite you with madness, and blindness and confusion of the mind'.

The above attitudes or mind led those who perceived themselves to be normal as normal, and others who do not look like them as abnormal. This process led them to reject, harm, exclude from society or refuse to associate with them, and eventually even kill them, if necessary. A good example is clearly seen in the treatment and killing of people with albinism. A number of them are killed for muti [African medicine which brings luck]. The media has shared some of these treatments and killings they received from Uganda, Tanzania, and South Africa, etc. This is one of the reasons that causes their family to hide the differently abled people from communities in order to avoid any form of public ridicule. The readers can now understand the reason why people born with disabilities are hidden from society by their families. Some of the reasons include rejection, isolation and discrimination. Santos (2003) expands on this issue and makes it clear the fear families have when one is born with disabilities. The above discussion makes me ask a vital question which needs to be answered by those who perceive themselves as normal people, and even the African church that needs to care for people of God irrespective of their disabilities. Santos (2003:46) asks, '[w] hat is the difference between people with and without disability in the eyes of God?' Before we can answer this question, we need to analyse our attitudes that have led us into negative relationships with people with disability strictly. It is also interesting to analyse how literature views disability. Let me share few of the terms and definitions shared by them.

\section{Terms defined by literature}

The term 'disability' is often used interchangeably with the words 'handicap' and 'impairment' in the literature. According to Ugorji (2004:10-11), '[t]he term disability could be understood from people with impairment from participating fully in the society or oppressive structures that inhibit them in the process within the community'. In other words, the surroundings are inaccessible and this is where people with disability find themselves in Africa and the global world. They are limited by structures in society that accommodate those who are able to physically use buildings that have no access to people with disabilities. The question to ask is, 'who is handicapped, us or them?' and 'why do we create structures that isolate others in order to function in the community?'

The World Health Organization (WHO) explains impairment as ' $[a] n$ impairment which refers to any loss or abnormality of psychological, physiological or abnormal structure or function' (https://www.ascleiden.nl/content/webdossiers/ disability-africa). In other words, disability is any restriction or lack resulting from an impairment or disability to perform an activity in the manner or within the range considered as normal for a human being. Disability can appear in various forms, such as physical disabilities that affect a person's mobility or dexterity (e.g. quadriplegic multiple sclerosis, cerebral palsy, absent limb, reduced limb, polio, etc.). The social stigma associated with disability is derived from all these perspectives (Ndukwe 2013:68).

The term 'handicap' implies that an impaired person is socially disadvantaged and may be discriminated against for deviating from social norms. All the above definitions make this not only a health problem but also a complex phenomenon reflecting the interaction between features of a person's body and features of the society in which he or she lives.

In an African community, the differently abled are also viewed as people who avert impending danger or impairment 
that might come upon them as a result of relating with a cursed family. The African church failed to theologically address this problem, especially based on creation of human beings in the image and likeness of God. If members of the church continue to nurture this myth of stigma, isolation and rejection because of viewing them as people who have no image and likeness of God, it will lead them to treat them as objects. For example, a number of African (black) churches do not have ramps in order to accommodate people with disability to access the building; this act also fails to give persons with disability an opportunity to socialise with people considered as able-bodied. The results lead others into depression and could result in suicide because of discrimination within the community. The main problem faced by African people is that they define disability and name it as it relates to the body part that does not function normally (using Oliver's [2008:308] words). The reader needs to note Oliver's further suggestion that 'language also plays an important part in discriminate against people with disability' (Oliver 2008:308). This leads to people describing those with impairment as non-human being. The African church which is supposed to care for them theologically adds insult to injury by referring to them as people who are cursed by God. In some of the charismatic, Pentecostal churches, people with disability are regarded as a sign of prayerlessness and weakness. Hence, they want to heal them so that they would look like them. They want to combat or excise the promises of Scripture and the ability of the church by attacking the demons that are seen as the causes of such deformities. For example, when people with disability come to worship, they are seen as people seeking healing from their disability (Black 1996). When they are not healed, they are blamed as being people with less faith. The African church needs to respect them, and thus enter into their space with holiness, and let the agenda of healing take a secondary place. We need to stop thinking that when they come to church they seek to be healed. If they are not healed, we need to stop blaming people for not having enough faith. This way of pastoral care destroys God's image in us who think we are normal. Kunhiyop (2012) states that:

Many African Churches feel that the presence of person with disabilities dampens their acclaimed confession as living churches, and therefore efforts are made to discourage people with disabilities from continuous coming to church, or repelled from joining in the worship life of church. (p. 42)

Time has come that we respect and allow people to worship freely, and not place our agenda on them. Pastors need to be sensitive to the needs of people who come to worship. Thomson (1997) connects to the above by saying that:

Persons with disability are treated like second class citizens, and object of charity, and are never granted enough space to take part in worship in the life of the (African) Church. (p. 42, [author's own italics])

\section{Pastors in worship}

People with disability intimidate pastors. As a result, they ostracise them because when they are not healed it weakens their reputation as men of God, and it portrays them as people who are unable to perform miracles (Oliver 1996:30). They then transfer their negative attitude to them. The African church needs to ask this question. Is it wrong for people with disability to enjoy worship? Each time they come to church, they are visualised as people who seek healing. I am also aware that the mainline churches have failed in pastorally to care for people with disabilities. They feel abandoned, marginalised, embarrassed and, in many cases, offended by treatment meted out to them by members of the church. For example, the black churches in particular do not have ramps, which is a sign of not being welcomed in the church. In other words, the architectural design keeps them at a distance, while some of the clergy are sensitive to their needs, especially in preaching the word of God. Their sermons are centred on God's mercy and kindness to the suffering of the disabled. Sin is seen as the major reason for their disabilities. The focus is based on how God can remove these infinities from those who have faith. They are finally seen as people who are cursed, as lacking faith and are wretched. As mentioned before, this issue also brings a burden to their parents because they feel that they have offended God. In brief, their God is cruel, who watches those who default. I do not want to research or talk about them entering into ministry or going for ordination. This process will lead us to destruction. It will also make us treat them like objects. The readers cannot be surprised when pastors focus on Romans 8:19-21, which is based on healing and cure. Some clergy argue that persons with disabilities eagerly wait for the liberation of their body from the bondage of decay, and before they are brought into the glorious freedom of Christ in bodily form (cure). When are we going to accept people with disability to worship freely as God's people rather than focus on healing their bodies? Pastoral care does not only focus on the body but also on spiritual healing, which is part of pastoral care.

Reinders (2013) shares an insight of Paul regarding suffering and frustration, among God's children, which needs to be analysed. Paul in 2 Corinthians 4:8-10 talks about afflictions, crushed down, perplexed and driven to despair.

Using the readers response approach, there is no other experience that comes closer to the categories used by Paul than the experiences of persons with disabilities. The role of the African church should be to ensure that they are not crushed, abandoned, forsaken and destroyed. The so-called normal people need to be liberated from this sinful way of thinking that people with disability are not complete human beings.

Some preachers will use Paul as a way of focusing on groaning and eager waiting for the redemption of the body. Finally, they will encourage those with disabilities to wait patiently in the hope for healing. Do they have to be healed all the time they come to worship? Other preachers have used this as a showcase and agree with the suffering and groaning of persons with disabilities that they are suffering not by their own choice but as allowed by the creator. 
They forget that God is merciful and kind, ready to forgive our sins. The author is of the opinion that if the will is based on healing and cure, then the African church should create a space for person with disabilities and encourage them to patiently wait in hope, including those who are not sick. We must also balance the above with spiritual healing, which often is not taken care of.

We now need a theology that will help us to reconstruct a full understanding that persons with disabilities are also created in the image and likeness of God, and thus they can and must participate in the worship life of the church. Note that God also loves them. We therefore need to leave our agenda of healing aside and receive them as God's people who are created in the image and likeness of God. In this way, they will also heal us from our prejudices and stigma that hinder us from receiving them as God's children. The African church can no longer afford to discriminate against them, and reinforce the exclusion of people who does not belong to worship life of the church. Longchar (2011:47) has identified two positions of weakness of the African church: (1) the interpretation of physical impairment as the work of demons and the result of sin and (2) the denial that people with disability are created in the image of God. In brief, some of the African churches fail to affirm people with disabilities. They are bound by cultural norms, which affect their theological interpretation of disabilities.

The challenge faced is that the African church should really analyse how African culture has dictated the above issue into negative attitude in their theology. Hence, they consider people who are straight and normal (so called) to be favoured by God. They are now given high respect and due regards in the African community. Abraham's (2007:138) summary was correct, ' $[h]$ e noted that the idea of perfection and beauty that are ingrained in peoples psyche and sanctioned by culture tend to preclude any form of disabilities'. Ogechi and Jerop (2002) will connect shame to the above experience, but saying that ' $[i] \mathrm{t}$ is only when feelings are not expressed that we swallow shame'. In other words, swallowing shame is what creates internal problem, especially for those we are caring for. Some of our churches affect people in such a way that they carry burdens of shame instead of being healed. Clergy and caregivers need to analyse their position of healing.

With the above discussion in mind, let me ask this question, who is disabled now? As I wrote this article, I realised how I was disabled in the way I was dealing with people with disabilities. I was excluding others who did not look like me, and forcing them to look like me. In brief, I became God who framed people according to my own image - not God's image. I kept them as people dependent on me; as a result, the community and I denied them participation in the community, excused them from work and excluded them from economic and educational rights. The above way of dealing with them led them into poverty, voiceless and powerlessness. Let me conclude by saying that when it comes to the African church, disabled people are ruled out of sight because they are not human beings, and they are not able to contribute financially. This process further renders them hopeless, desolated and stigmatised in the community. The reader needs to note that they are isolated and rejected daily. That is why members of the family get discouraged because they feel unwelcome in the body of Christ. Note that the healing and caring church has become a thorn in the flesh (using Paul's words of pain and suffering). This notion of disability resulting as a wrath of God causes the disabled person with his or her family to often experience stigmatisation, and this can influence a family in such a way that they will then try to hide the disabled member of their family (Wong 2014:29). The concentration and focus on this experience has been resurrected by my experience in Brazil (as an able-bodied person, so to speak). When I became unable because of language problem, I could not get directions to go to the hotel because no one could speak English. We struggled to communicate with each other, let alone getting the directions. At that point, I then felt disabled because I was not able to speak their language, and I could not get what I needed; even in the restaurant I was challenged by not getting the service of food I needed. I was also spiritually and mentally affected. This is how this research came into existence. Let me conclude this article, which challenged me to reflect on my own experiences of inadequacies.

\section{Conclusion}

As a pastoral care giver, I realised that there are several stories in scriptures that address the issue of disability in a pastoral way. It is interesting to note the Lord's approach in the way of caring for people with special needs. He never forced himself on them, but exercised his ministry by respecting those who were sick, blind and the crippled. Note that Mark and Luke have a similar account on how our Lord cared for the sick within the community in Palestine. For example, the story of Bartimaeus in Mark 10 and the story in Luke 14 share a great light on how we should deal with human beings with special needs. In Mark, the story unfolds in the following way:

${ }^{46}$ 'and they came to Jericho. And as he was leaving Jericho with his disciples and a great crowd, Bartimaeus, a blind beggar, the son of Timaeus, was sitting by the roadside. ${ }^{47}$ And when he heard that it was Jesus of Nazareth, he began to cry out and say, 'Jesus, Son of David, have mercy on me!'48 And many rebuked him, telling him to be silent. But he cried out all the more, 'Son of David, have mercy on me!'49 And Jesus stopped and said, 'Call him.' And they called the blind man, saying to him, 'Take heart. Get up; he is calling you'. ${ }^{50}$ And throwing off his cloak, he sprang up and came to Jesus. ${ }^{51}$ And Jesus said to him, 'What do you want me to do for you?' And the blind man said to him, 'Rabbi, let me recover my sight'. ${ }^{52}$ And Jesus said to him, 'Go your way; your faith has made you well'. And immediately he recovered his sight and followed him on the way. (Mark 10:46-52)

What a classic way of dealing with people with disabilities. He never used his power until he knew what the person 
needed. For example, 'what do you want me to do for you?' are key words of how Jesus entered into Bartimaeus' space, or anyone who was sick, or who came for help. This is a great lesson for the African church, especially us (caregivers or clergy) who are called the anointed ones. These two gospel stories pose a great challenge to those who are caregivers and help us to treat God's people with dignity. The above scripture helps us to see how our Lord addresses perceptions that were held by the Jewish community in those days, which regarded any form of disability or suffering as the result of sin committed by the person, parents or close relatives. In Luke 14, the Parable of the Great Banquet is helpful to analyse those who were rejected by society or community:

${ }^{12} \mathrm{He}$ said also to the man who had invited him, 'When you give a dinner or a banquet, do not invite your friends or your brothers or your relatives or rich neighbours, lest they also invite you in return and you be repaid. ${ }^{13}$ But when you give a feast, invite the poor, the crippled, the lame, the blind, ${ }^{14}$ and you will be blessed, because they cannot repay you. For you will be repaid at the resurrection of the just. (Luke14:12-14)

Christ shares great light to the above thought by restoring dignity to those who are in need. It is important to avoid imposing our own agenda on them. Even the disciples were caught in this cultural paradigm.

In other words, boundaries were erected between people with disabilities and the so-called straight people. Note once again that Our Lord's pastoral response was rebuking people who excluded persons with disabilities in the community and religious life. His pastoral intervention attaches or restores holiness or blessedness to the action of inclusion. He addressed the story of the blind man in a different way - a careful reading presents the Messiah as a Redeemer who came to liberate and set free persons who were oppressed, ostracized (especially the poor) and stigmatised by culture, religion and tradition. This can help the African church to articulate its theology and approach to persons with disabilities. It gives us a new perspective of doing theology of pastoral care. His response: ' $[i] \mathrm{t}$ was not that this man sinned or his parents, or relatives, but that the work of God might be made manifested in him' (John 9:3). In Luke 14, '[w]e are therefore called to a new theology of inclusion, especially if persons are excluded from temple' (in our case, village, society or community).

My argument is calling us to affirm people in the African church. It should be a place where human beings are welcome, irrespective of who they are (rich or poor, gay or straight, abled and disabled, etc.). This will help the church to be a fully caring and loving church. In brief, it will be following in the footstep of the Master. As a pastoral caregiver, I am calling on charismatic as well as mainline churches to care for God's children. When those who are isolated are included, we could become the church of our Lord Jesus Christ that is the community that cares for those in periphery. In other words, our lord brought people from the periphery to the centre of life in his ministry. Therefore, if we exclude these people, we remain incomplete without addressing the issues discussed in this article. We can only do this when we read our scriptures with a new understanding. Kabue (2011:49), an elder of the Presbyterian church of East Africa, has helped me to see God in people with disability as a blind man. He says (Kabue 2011):

The discrimination, prejudices and exclusion have serious consequences on the lives of persons with disabilities. He finally discourage $[s]$ the separate treatment in the realm of Spiritual things meted out against people with disabilities. (p. 49)

Finally, Galgalo et al. (2011) called on the church to dig deep into the Word of God in order to understand God's will and promise to persons with disabilities, which will ultimately help to cater or care for their spiritual aspirations and specific spiritual needs. That is our challenge; the above will move the church from neglect (periphery) into caring for God's people. They will become the centre in their ministry. This process will allow us to enter into the space of person with disability, and we will then allow them to set their own agenda instead of our agenda. This is our calling and ministry in these days of violence, abuse, rejection and stigmatisation.

\section{Acknowledgements Competing interests}

The author has declared that no competing interests exist.

\section{Author(s) contributions}

I declare that I am the sole author of this research article.

\section{Ethical consideration}

This article followed all ethical standards for a research without direct contact with human or animal subjects.

\section{Funding Information}

This research received no specific grant from any funding agency in the public, commercial, or not-for-profit sectors.

\section{Data availability statement}

Data sharing is not applicable to this article as no new data were created or analysed in this study.

\section{Disclaimer}

The views and opinions expressed in this article are those of the authors and do not necessarily reflect the official policy or position of any affiliated agency of the authors.

\section{References}

Abraham, K., 2007, 'Theological reflections on persons with disability,' Voices from the Third World 30(1), 116-127.

Black, C., 1996, A healing homiletic: Preaching and disability, Abingdon Press, Nashville, TN.

Galgalo, J., Kabue, S., Mombo, E. \& Peter, C.B. (eds.), 2011, Disability, society and theology: Voices from Africa, Zapf Chancery Publishers Africa, Limuru. 
Kunhiyop, S.W., 2012, African Christian Theology, Zondervan, Grand Rapids, MI.

Kabue, S., 2011, 'Persons with disability in church and society. A historical and sociological perspective', in J. Galgalo, S. Kabue, E. Mombo \& C.B. Peter (eds.), Disability, society and theology: Voices from Africa, pp. 3-24, Zapf Chancery Publishers Africa, Limuru.

Longchar, W.A., 2011, 'Sin suffering and disability in God's world', in J. Galgalo, S. Kabue, E. Mombo \& C.B. Peter (eds.), Disability, society and theology: Voices from Africa, pp. 47-58, Zapf Chancery Publishers Africa, Limuru.

Ndukwe, O., 2013, Celebration of life: Religion, mission and the victims of society. Nigeria, Precious Publications, Ohafia.

Ogechi, N.O. \& Jerop, R.S., 2002, 'Portrayal of disability through personal names and proverbs in Kenya; evidence from Ekegusii and Nandi', Vienna Journal of African 3.

Oliver, M., 1996. Understanding disability, from theory to practice, Macmillan Press Ltd., London.
Oliver, T., 2008, Disability and the myth of personal tragedy. Sociology themes and perspectives, 7th edn., Harper Collins Publications Limited, London.

Reinders, H.S., 2013, Theology and disability, searching for dignity: Conversation on humanity, Theology and Disability Publication, viewed May 27, 2019, from http:// www.ascleidm.nlkontek/webdossiers/disability-Africa.

Santos, C., 2003, Why do employment hire or do not hire persons with disability, College of Mass Comminication, University of the Philippines, Quezon City.

Thomson, R.G., 1997, Extraordinary bodies: Figuring physical disability in American culture and literature, Columbia University Press, New York.

Ugorji, L.I., 2004, Making able in disability, Snaap Press, Enugu.

Wimberly, E.P., 1999, Moving from shame to self-worth, Abingdon Press, Nashville, TN.

Wong, H.H., 2014, 'Jesus and the disabled people: A church response to the disability', in G. Cowan \& W.A. Longchar (eds.), Doing theology from disability perspective: A theological resource book on disability, vol. 55, no. 3, pp. 247-265, Association for Theological Education journal in South East Asia, Manila. 